\title{
PENGARUH IKLAN TELEVISI DAN CITRA MEREK TERHADAP KEPUTUSAN PEMBELIAN PRODUK MEREK WARDAH DI KOTA PALU
}

\author{
SITI RISKIANA \\ CHALIL \\ IRA NURIYA SANTI \\ Program Studi S1 Manajemen, Fakultas Ekonomi, Universitas Tadulako \\ Email: sitiriskiana@gmail.com
}

\begin{abstract}
The purpose of this study is to know and analyze the influence of television advertising and brand image simultaneously and partially to the purchase decision of Wardah brand product in Palu City. The variables of this research are television advertisement (X1) and brand image (X2). While the dependent variable is the purchase decision $(Y)$. The research method used is descriptive method causal with the number of sample 75 people. Form of sampling using purposive sampling technique. Data analysis method used in this research is multiple linear regression analysis method. The results showed that: 1). Television advertisement and brand image simultaneously have a significant effect on the purchasing decision of Wardah brand products; 2). Television advertisement partially significant effect on purchasing decision of Wardah brand product; 3). Brand image partially significant effect on purchasing decision of Wardah brand product in Palu City.
\end{abstract}

Keywords: Television Advertisement, Brand Image, Purchase Decision

\begin{abstract}
Abstrak
Tujuan penelitian ini adalah untuk mengetahui dan menganalisis pengaruh iklan televisi dan citra merek secara simultan dan parsial terhadap keputusan pembelian produk merek Wardah di Kota Palu. Variabel penelitian ini yaitu iklan televisi $\left(\mathrm{X}_{1}\right)$ dan citra merek $\left(\mathrm{X}_{2}\right)$. Sedangkan variabel dependen yaitu keputusan pembelian (Y). Metode penelitian yang digunakan adalah metode deskriptif kausal dengan jumlah sampel 75 orang. Bentuk pengambilan sampel menggunakan teknik purposive sampling. Metode analisis data yang digunakan dalam penelitian ini adalah metode analisis regresi linear berganda. Hasil penelitian menunjukan bahwa: 1). Iklan Televisi dan Citra Merek secara simultan berpengaruh signifikan terhadap keputusan pembelian produk merek Wardah; 2). Iklan Televisi secara parsial berpengaruh signifikan terhadap keputusan pembelian produk merek Wardah; 3). Citra Merek secara parsial berpengaruh signifikan terhadap keputusan pembelian produk merek Wardah di Kota Palu.
\end{abstract}

Kata Kunci: Iklan Televisi, Citra Merek, Keputusan Pembelian

\section{PENDAHULUAN}

Membanjirnya produk kosmetik di pasaran mempengaruhi minat seseorang terhadap pembelian dan berdampak pada keputusan pembelian. Pembelian suatu produk kosmetik bukan lagi hanya untuk memenuhi keinginan (wants) saja, tetapi sudah menjadi sebuah kebutuhan (needs) pada saat ini. Ketatnya persaingan dalam bisnis kosmetik di Indonesia, menuntut perusahaan agar lebih kreatif dan inovatif dalam memasarkan produknya. Salah satu komponen dalam marketing mix yang umum dilakukan perusahaan adalah iklan. Iklan sebagai pengingat sangat penting bagi produk karena periklanan membantu memelihara hubungan pelanggan dengan membuat konsumen terus memikirkan produk (Kotler \& Armstrong, 2008:152). Aspek yang juga sangat penting adalah citra dari merek produk itu sendiri. Menurut Kotler \& Keller (2009:403) citra merek adalah persepsi dan keyakinan yang dipegang oleh konsumen, seperti yang di cerminkan asosiasi yang tertanam dalam ingatan konsumen, yang selalu diingat pertama kali mendengar.

Keputusan pembelian konsumen yang tinggi dapat mengakibatkan tingginya volume penjualan sehingga keuntungan yang akan didapat oleh perusahaan semakin tinggi. Salah satu produk kosmetik yang memiliki peningkatan penjualan tertinggi yaitu produk kosmetik merek Wardah. Wardah 
Riskiana, S.

diproduksi oleh PT. Paragon Technology and Innovation berdiri pada tanggal 28 Februari 1985 dengan nama awal PT. Pusaka Tradisi Ibu. Perusahaan ini baru berganti nama menjadi PT. Paragon Technology and Innovation pada tahun 2011. Demi menjaga citra dari merek Wardah, Wardah selalu melakukan pembaharuan produk dengan memunculkan produk-produk baru kemudian mengiklankannya dengan cara yang lebih kreatif dan inovatif, sehingga dapat menjadi merek kosmetik yang paling disukai serta meningkatkan citra dan kepercayaan diri penggunaannya.

Wardah merupakan produk kosmetik yang bisa dikatakan baru memasuki industri kosmetik di Indonesia. Walaupun terbilang baru, namun Wardah sudah memiliki positioning pada industri kosmetik di Indonesia yaitu kosmetik yang berlabel halal dan berhasil menarik perhatian dari segmen wanita Muslim. Bisa dikatakan pula bahwa Wardah dapat menyaingi merek dari produk kosmetik yang lebih lama berada di industri kosmetik Indonesia, misalnya Mustika Ratu yang telah ada sejak tahun 1978, Sari Ayu pada tahun 1977 dan Viva yang telah berdiri pada tahun 1962.

Berdasarkan fenomena Wardah dapat menyaingi merek kosmetik yang lebih dulu ada dalam waktu yang cepat, maka perlu adanya penelitian yang bertujuan untuk mengetahui mengapa Wardah dapat menyaingi merek kosmetik lain dengan meneliti iklan televisi dan citra merek terhadap keputusan pembelian produk merek Wardah di Kota Palu.

Adapun tujuan yang ingin dicapai dalam penelitian ini adalah:

1. Untuk mengetahui pengaruh iklan televisi dan citra merek secara simultan terhadap keputusan pembelian produk merek Wardah di Kota Palu.

2. Untuk mengetahui pengaruh iklan televisi secara parsial terhadap keputusan pembelian produk merek Wardah di Kota Palu.

3. Untuk mengetahui pengaruh citra merek secara parsial terhadap keputusan pembelian produk merek Wardah di Kota Palu.

\section{KAJIAN LITERATUR DAN PENGEMBANGAN HIPOTESIS}

\section{Iklan Televisi}

Menurut Kotler \& Keller (2012:507) iklan televisi umumnya diakui sebagai media periklanan yang paling kuat dan menjangkau spektrum konsumen yang luas dengan biaya rendah per eksposur. Iklan TV memiliki dua kekuatan yang sangat penting. Pertama, dapat dengan jelas menunjukkan atribut produk dan secara persuasif menjelaskan manfaat konsumen mereka yang sesuai. Kedua, secara dramatis dapat menggambarkan citra pengguna dan penggunaan, kepribadian merek, dan hal-hal tak berwujud lainnya.

\section{Dimensi Iklan Televisi}

Dimensi iklan televisi yang digunakan merupakan dimensi menurut Istijanto (2005:224) yaitu:

1. Nilai informasi, bertujuan untuk menciptakan kesadaran merek dan pengetahuan akan produk baru atau fitur baru dari produk yang ada.

2. Keyakinan membeli, berusaha menciptakan keinginan, preferensi, keyakinan, dan pembelian produk.

3. Citra sosial, bertujuan untuk meyakinkan pembeli saat ini bahwa mereka membuat pilihan yang tepat dengan mempertimbangkan citra dari produk tersebut yang akan berdampak pada citra pembeli.

\section{Citra Merek}

Menurut Undang-Undang Merek No. 15 Tahun 2001 pasal 1 ayat 1, Tjiptono (2011:3) menjelaskan bahwa merek adalah tanda yang berupa gambar, nama, kombinasi, dari unsur-unsur tersebut yang memiliki daya pembeda dan digunakan dalam kegiatan perdagangan barang atau jasa. Perkembangan terakhir menunjukan bahwa bentuk, suara hologram, dan bahkan aroma juga dimasukan dalam lingkup definisi merek. Menurut Tjiptono (2011:49) pengertian Brand Image (citra merek) adalah deskripsi tentang asosiasi dan keyakinan konsumen terhadap merek tertentu. Bisa dikatakan bahwa citra merek adalah persepsi konsumen mengenai suatu merek tersebut.

\section{Dimensi Citra Merek}

Citra merek memiliki beberapa indikator-indikator yang mencirikan citra merek tersebut. Menurut Rangkuti (2009:44) bahwa terdapat beberapa indikator yang harus diperhatikan dalam membentuk sebuah citra merek, yaitu: 
1. Recognition (Pengenalan), tingkat dikenalnya sebuah merek oleh konsumen.

2. Reputation (Reputasi), tingkat atau status yang cukup tinggi bagi sebuah merek karena telah terbukti mempunyai "track record" yang baik.

3. Affinity (Daya Tarik), semacam daya tarik yang mempunyai hubungan emosional dengan konsumennya.

4. Brand Loyalty (Kesetiaan Merek), menyangkut ukuran dari kesetiaan pelanggan terhadap suatu merek yang bersangkutan.

\section{Keputusan Pembelian}

Menurut Kotler \& Armstrong (2008:181) Keputusan pembelian adalah keputusan pembeli tentang merek mana yang dibeli. Pengertian lain keputusan pembelian adalah keputusan konsumen mengenai preferensi atas merek-merek yang ada di dalam kumpulan pilihan (Kotler \& Keller, 2012:170). Jadi keputusan pembelian yaitu perilaku konsumen dalam memilih salah satu merek dari banyaknya merek yang ada.

\section{Kerangka Pemikiran}

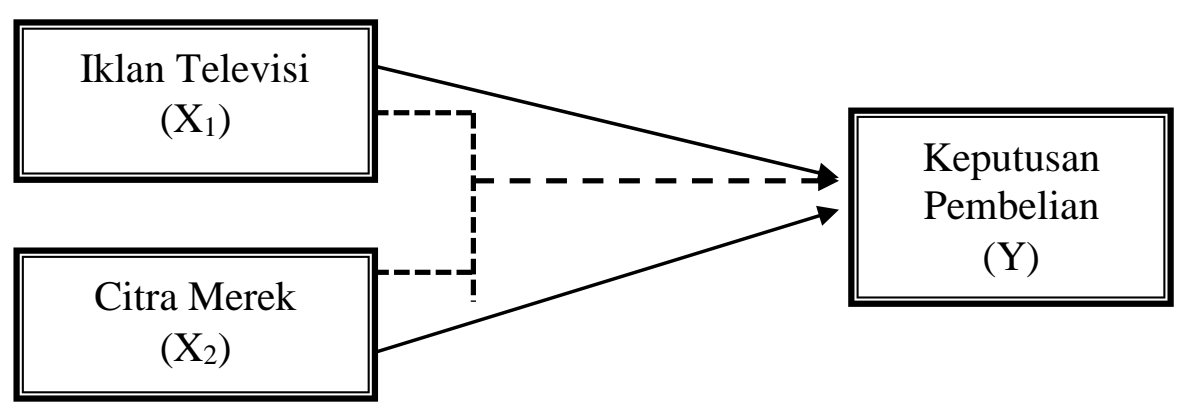

Keterangan:

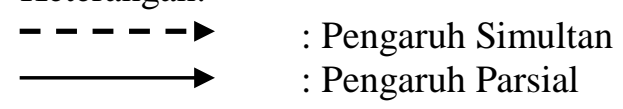

Gambar 1. Kerangka Pemikiran

\section{Hipotesis}

Berdasarkan latar belakang dan kerangka pemikiran di atas, dugaan sementara yang diajukan oleh peneliti dalam penelitian ini atas masalah yang telah dirumuskan adalah sebagai berikut:

1. Iklan televisi dan citra merek secara simultan berpengaruh signifikan terhadap keputusan pembelian produk merek Wardah di Kota Palu.

2. Iklan televisi secara parsial berpengaruh signifikan terhadap keputusan pembelian produk merek Wardah di Kota Palu.

3. Citra merek secara parsial berpengaruh signifikan terhadap keputusan pembelian produk merek Wardah di Kota Palu.

\section{METODE PENELITIAN}

Jenis penilitian ini adalah penelitian deskriptif dan kausal, menurut Sugiyono (2014:53) Penelitian deskriptif adalah rumusan masalah yang berkenaan dengan pernyataan terhadap keberadaan variabel mandiri, baik hanya satu variabel atau lebih. Adapun menurut Sugiyono (2012:38) Objek penelitian (variabel penelitian) adalah segala sesuatu yang berbentuk apa saja yang ditetapkan oleh peneliti untuk dipelajari sehingga informasi tentang hal tersebut, kemudian ditarik kesimpulannya. Objek dalam penelitian ini adalah pengaruh iklan televisi dan citra merek sebagai variabel yang memengaruhi (independen) sedangkan variabel yang dipengaruhi (dependen) ialah keputusan pembelian produk merek Wardah di Kota Palu.

Populasi adalah wilayah generalisasi yang terdiri dari objek atau subjek yang mempunyai kualitas dan karakteristik tertentu yang ditetapkan oleh peneliti untuk dipelajari dan kemudian ditarik kesimpulannya (Sugiyono, 2015:119). Populasi dalam penelitian ini adalah masyarakat Kota Palu yang telah membeli dan menggunakan produk kosmetik merek Wardah.. Metode pengambilan sampel yang digunakan dalam penelitian ini adalah non-probability sampling dan menggunakan teknik 
Riskiana, S.

purposive sampling yaitu teknik penentuan sampel dengan pertimbangan tertentu. Adapun kriteriakriteria responden yang dijadikan sampel pada penelitian ini adalah sebagai berikut:

1. Pernah melihat iklan produk Wardah di televisi

2. Telah membeli dan menggunakan produk Wardah

3. Bersedia mengisi kuesioner yang diberikan

4. Minimal berusia 17 tahun

Jumlah sampel yang diambil untuk mewakili populasi dalam penelitian ini sebanyak 75 sampel. Penentuan sampel sebanyak 75 responden, ini didasarkan pada teori teori Roscoe dalam Sugiyono (2016:102-103) bila dalam penelitian akan melakukan analisis dengan multivariate (korelasi atau regresi berganda misalnya), maka jumlah anggota sampel minimal 10 kali dari jumlah variabel yang diteliti (independen + dependen).

\section{Pengujian Instrumen Penelitian}

Sebelum data dikumpulkan dan diolah, maka sebelumnya peneliti perlu melakukan uji coba instrumen terlebih dahulu, guna menegetahui tingkat validitas dan reliabilitas suatu instrument.

\section{Uji Validitas}

Uji validitas bertujuan untuk menguji sejauh mana ketepatan alat pengukur dapat mengungkapkan konsep gejala/kejadian yang diukur. Instrument yang valid berarti alat ukur yang digunakan untuk mendapatkan data itu valid. Valid berarti instrumen tersebut dapat digunakan untuk mengukur apa yang seharusnya diukur (Sugiyono, 2014:203). Syarat minimum untuk dianggap memenuhi syarat adalah $\mathrm{r}=0.3$. Jadi, korelasi antara butir dengan skor total kurang dari 0.3 maka butir dalam instrument tersebut dinyatakan tidak valid. Sebaliknya, bila skor total sama dengan 0.3 atau lebih (paling kecil 0.3) maka instrumen tersebut dinyatakan valid (Sugiyono, 2014:188).

\section{Uji Reliabilitas}

Ghozali (2013:47) mengemukakan bahwa uji reliabilitas adalah alat untuk mengukur suatu kuesioner yang merupakan indikator dari variabel atau konstruk. Suatu kuesioner dikatakan reliabel atau handal jika jawaban seseorang terhadap pertanyaan adalah konsisten atau stabil dari waktu ke waktu. Peneliti mengukur reliabelnya suatu variabel dengan cara melihat Cronbach Alpha dengan signifikansi yang digunakan lebih besar dari 0.60. Suatu konstruk atau variabel dikatakan reliabel jika memberikan nilai Cronbach Alpha > 0.60 (Ghozali, 2013:48).

\section{Metode Analisis}

1. Uji Normalitas

Uji Normallitas digunakan untuk menguji apakah dalam sebuah model regresi variabel (pengganggu) dependen dan independen atau keduanya memiliki distribusi normal (Ghozali, 2013:160). Model regresi yang baik adalah distribusi data normal atau mendekati normal. Deteksi normalitas dilakukan dengan melihat penyebaran data (titik) pada sumbu diagonal dan grafik.

2. Uji Multikolinieritas

Uji Multikolinieritas digunakan untuk menguji apakah model regresi ditemukan adanya kolerasi antara variabel bebas independen. Model regresi yang baik seharusnya antara variabel independen tidak terjadi korelasi antara variabel independen (Ghozali, 2013:105).

3. Uji Heteroskedastisitas

Menurut Ghozali (2013:139) uji heteroskedastisitas yaitu untuk menguji apakah dalam model regresi terjadi ketidaksamaan variance dari residual satu pengamatan ke pengamatan yang lain. Jika variance dari residual satu pengamatan ke pengamatan lain tetap, maka disebut homoskedastisitas dan jika berbeda disebut heteroskedastisitas Model regresi yang baik adalah tidak terjadi heteroskedastisitas.

4. Regresi Linear Berganda

Untuk menguji pengaruh variabel iklan televisi dan citra merek terhadap keputusan pembelian produk merek Wardah maka digunakan alat uji statistik yaitu regresi linear berganda yang dapat dirumuskan (Sugiyono, 2012:262):

$$
\mathbf{Y}=\mathbf{a}+\mathbf{b}_{1} \mathbf{X}_{1}+\mathbf{b}_{2} \mathbf{X}_{2}+\mathbf{e}
$$




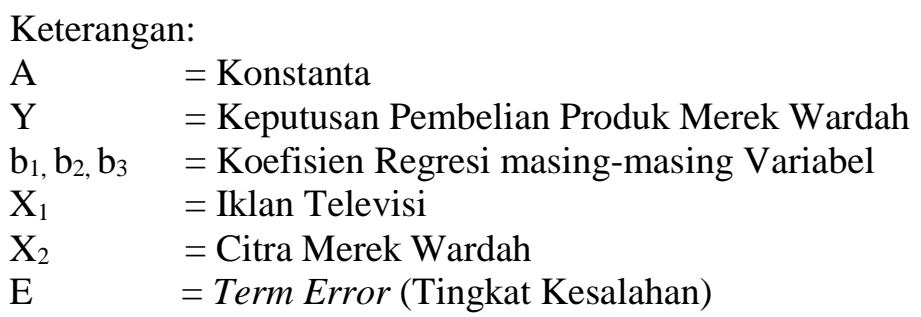

\section{HASIL DAN PEMBAHASAN} Hasil Uji Validitas dan Reliabilitas

Berikut ini adalah hasil uji validitas dan reliabilitas atas item pernyataan yang terdapat dalam kuesioner penelitian terhadap variabel iklan televisi (X1), citra merek (X2) dan keputusan pembelian (Y). Adapun hasilnya disajikan dalam tabel 1 berikut:

Tabel 1. Hasil Uji Validitas dan Reliabilitas Instrumen Penelitian

\begin{tabular}{|c|c|c|c|c|c|}
\hline Variabel & Item & $\begin{array}{c}\text { Total } \\
\text { Correlation }\end{array}$ & Ket & $\begin{array}{c}\text { Cronbach } \\
\text { Alpha }\end{array}$ & Ket \\
\hline \multirow{9}{*}{$\begin{array}{l}\text { Iklan Televisi } \\
\text { (X1) }\end{array}$} & X1.1 & 0,619 & Valid & \multirow{9}{*}{0,853} & \multirow{9}{*}{ Reliabel } \\
\hline & $\mathrm{X} 1.2$ & 0,544 & Valid & & \\
\hline & $\mathrm{X} 1.3$ & 0,701 & Valid & & \\
\hline & $\mathrm{X} 1.4$ & 0,637 & Valid & & \\
\hline & $\mathrm{X} 1.5$ & 0,619 & Valid & & \\
\hline & X1.6 & 0,678 & Valid & & \\
\hline & $\mathrm{X} 1.7$ & 0,441 & Valid & & \\
\hline & X1.8 & 0,486 & Valid & & \\
\hline & X1.9 & 0,436 & Valid & & \\
\hline \multirow{12}{*}{$\begin{array}{l}\text { Citra Merek } \\
\text { (X2) }\end{array}$} & $\mathrm{X} 2.1$ & 0,356 & Valid & \multirow{12}{*}{0,826} & \multirow{12}{*}{ Reliabel } \\
\hline & $\mathrm{X} 2.2$ & 0,472 & Valid & & \\
\hline & X2.3 & 0,559 & Valid & & \\
\hline & X2.4 & 0,495 & Valid & & \\
\hline & $\mathrm{X} 2.5$ & 0,534 & Valid & & \\
\hline & X2.6 & 0,627 & Valid & & \\
\hline & $\mathrm{X} 2.7$ & 0,346 & Valid & & \\
\hline & $\mathrm{X} 2.8$ & 0,556 & Valid & & \\
\hline & X2.9 & 0,311 & Valid & & \\
\hline & $\mathrm{X} 2.10$ & 0,604 & Valid & & \\
\hline & $\mathrm{X} 2.11$ & 0,483 & Valid & & \\
\hline & $\mathrm{X} 2.12$ & 0,418 & Valid & & \\
\hline \multirow{5}{*}{$\begin{array}{c}\text { Keputusan Pembelian } \\
\text { (Y) }\end{array}$} & Y1.1 & 0,383 & Valid & \multirow{5}{*}{0,693} & \multirow{5}{*}{ Reliabel } \\
\hline & Y1.2 & 0,384 & Valid & & \\
\hline & Y1.3 & 0,439 & Valid & & \\
\hline & Y1.4 & 0,600 & Valid & & \\
\hline & Y1.5 & 0,409 & Valid & & \\
\hline
\end{tabular}

Berdasarkan hasil uji validitas dan reliabilitas diperoleh bahwa seluruh variabel memiliki koefisien Cronbach Alpha (a) lebih besar dari 0,60 sehingga berdasarkan syarat minimum reliabilitas lebih besar dari 0,60 maka seluruh variabel yang digunakan reliabel dan dapat digunakan dalam penelitian ini. Sedangkan uji validitas terhadap seluruh variabel juga menunjukan nilai koefisien korelasi yang lebih besar dari 0,30 sehingga item pernyataan yang ada valid untuk digunakan. 


\section{Hasil Uji Analisis Regresi Linear Berganda}

Penelitian ini menggunakan analisis regresi linear berganda dengan tujuan untuk menguji pengaruh iklan televisi dan citra merek terhadap keputusan pembelian. Untuk lebih jelasnya hasil analisis regresi linear berganda dapat dilihat pada tabel 2 berikut:

Tabel 2. Hasil Uji Regresi Linear Berganda

\begin{tabular}{|c|c|c|c|c|c|c|}
\hline \multicolumn{7}{|c|}{ Dependen Variabel Y = Keputusan Pembelian } \\
\hline \multirow{2}{*}{\multicolumn{2}{|c|}{ Variabel Independen }} & \multicolumn{2}{|c|}{$\begin{array}{c}\text { Unstandardized } \\
\text { Coefficients }\end{array}$} & \multirow{2}{*}{$\begin{array}{c}\text { Standardized } \\
\text { Coefficients } \\
\text { Beta }\end{array}$} & \multirow[t]{2}{*}{$\mathbf{t}$} & \multirow[t]{2}{*}{ Sig. } \\
\hline & & B & Std. Error & & & \\
\hline \multirow{3}{*}{1} & (Constant) & .389 & .340 & & 2.477 & .256 \\
\hline & $\begin{array}{c}\mathrm{X} 1 \\
\text { (Iklan Televisi) }\end{array}$ & .256 & .083 & .296 & 5.243 & .003 \\
\hline & $\begin{array}{c}\mathrm{X} 2 \\
\text { (Citra Merek) } \\
\end{array}$ & .635 & .107 & .565 & 7.974 & .000 \\
\hline \multicolumn{2}{|c|}{ Multiple R } & $=0.790$ & \multicolumn{3}{|c|}{ Sig. $F=0.000$} & \\
\hline \multicolumn{2}{|c|}{ Adjusted R Square } & $=0,614$ & $=0$ & \multicolumn{2}{|c|}{$=0,05$ tingkat kepercayaan $95 \%$} & \\
\hline
\end{tabular}

Berdasarkan tabel 2 tersebut, dapat ditulis dalam bentuk persamaan regresi linear berganda. Untuk lebih jelasnya bentuk persamaan tersebut dapat dilihat sebagai berikut:

$$
\mathrm{Y}=0.389+0.256 \mathrm{X}_{1}+0.635 \mathrm{X}_{2}+\mathrm{e}
$$

Berdasarkan penjabaran tersebut menunjukkan bahwa, variabel independen yang dianalisis yaitu variabel $\left(\mathrm{X}_{1}\right.$ dan $\left.\mathrm{X}_{2}\right)$ memberikan pengaruh posotif terhadap variabel dependen $(\mathrm{Y})$, yaitu keputusan pembelian produk merek Wardah di Kota Palu. Untuk lebih jelasnya penjelasan bentuk persamaan tersebut dapat dilihat berikut ini:

1. Nilai Konstanta sebesar 0.389 , artinya jika variabel (Iklan televisi dan citra merek) bernilai 0, maka variabel dependen (keputusan pembelian produk merek Wardah di Kota Palu) nilainya sebesar 0.389 .

2. Koefisien regresi dimensi Iklan Televisi $\left(\mathrm{X}_{1}\right)$ sebesar 0.256, artinya jika iklan televisi naik satu satuan, maka keputusan pembelian produk merek Wardah di Kota Palu naik sebesar 0.256.

3. Koefisien regresi dimensi Citra Merek $\left(\mathrm{X}_{2}\right)$ sebesar 0.635 , artinya jika citra merek naik satu satuan, maka keputusan pembelian produk merek Wardah di Kota Palu naik sebesar 0.635.

\section{Hasil Uji Hipotesis}

\section{Hasil Pengujian Hipotesis Secara Simultan (Uji F)}

Tahap selanjutnya adalah menguji signifikan hubungan atau uji $\mathrm{F}$ antara variabel penelitian yaitu iklan televisi $\left(\mathrm{X}_{1}\right)$ dan citra merek $\left(\mathrm{X}_{2}\right)$ terhadap keputusan pembelian (Y) dengan perhitungan menggunakan SPSS 16.0 dengan hasil sebagai berikut:

Tabel 3. Hasil Uji F (Simultan)

\begin{tabular}{lrrrrr}
\hline & \multicolumn{1}{c}{ Sum of } & & & & \\
Model & Squares & Df & Mean Square & $F$ & Sig. \\
\hline 1 Regression & 14.932 & 2 & 7.466 & 59.808 & $.000^{\mathrm{a}}$ \\
Residual & 8.988 & 72 & .125 & \\
Total & 23.920 & 74 & & & \\
\hline
\end{tabular}


Berdasarkan tabel 3 di atas diperoleh Sig.F yaitu 0.000, artinya nilai tersebut lebih kecil dibandingkan dengan nilai yang disyaratkan yaitu $\alpha=0.05$ dengan tingkat kepercayaan $95 \%$. dengan demikian dapat dinyatakan bahwa secara simultan variabel Iklan Televisi dan Citra Merek secara simultan berpengaruh signifikan terhadap keputusan pembelian produk merek Wardah di Kota Palu.

\section{Hasil Pengujian Hipotesis Secara parsial (Uji t)}

Hasil Uji t adalah untuk mengetahui apakah variabel $\left(\mathrm{X}_{1}-\mathrm{X}_{2}\right)$ secara parsial berpengaruh terhadap Y. Untuk lebih jelasnya hasil dapat dilihat pada tabel 4 berikut:

Tabel 4. Hasil Uji t (Parsial)

\begin{tabular}{cccc}
\hline \multicolumn{1}{c}{ Model } & t & Sig \\
\hline \multirow{3}{*}{1} & (Constant) & 1.144 & .256 \\
& $\mathrm{X}_{1}$ & 3.107 & .003 \\
& $\mathrm{X}_{2}$ & $\underline{5.933}$ & .000 \\
& & &
\end{tabular}

Berdasarkan tabel 4 tersebut, hasil uji t pengujian variabel $\left(\mathrm{X}_{1}-\mathrm{X}_{2}\right)$ terhadap $\mathrm{Y}$ dijelaskan sebagai berikut:

\section{Hasil Pengujian Hipotesis $X_{1}$ terhadap $Y$}

Hipotesis kedua $\left(\mathrm{H}_{2}\right)$ adalah untuk mengetahui apakah Iklan Televisi $\left(\mathrm{X}_{1}\right)$ secara parsial berpengaruh signifikan terhadap keputusan pembelian produk merek Wardah di Kota Palu. Berdasarkan tabel di atas menunjukkan bahwa Iklan Televisi $\left(\mathrm{X}_{1}\right)$ memiliki nilai signifikan sebesar 0.003. Artinya nilai tersebut $<$ dari taraf yang disyaratkan yaitu $\alpha=0.05$, maka dapat disimpulkan bahwa secara parsial iklan televisi berpengaruh signifikan terhadap keputusan pembelian.

\section{Hasil Pengujian Hipotesis Hasil $X_{2}$ terhadap $Y$}

Hipotesis ketiga $\left(\mathrm{H}_{3}\right)$ adalah untuk mengetahui apakah Citra Merek $\left(\mathrm{X}_{2}\right)$ secara parsial berpengaruh signifikan terhadap keputusan pembelian produk merek Wardah di Kota Palu. Berdasarkan Tabel di atas menunjukkan bahwa Citra Merek $\left(\mathrm{X}_{2}\right)$ memiliki nilai signifikan sebesar 0.000. Artinya nilai tersebut $<$ dari taraf yang disyaratkan yaitu $\alpha=0.05$, maka dapat disimpulkan bahwa secara parsial Citra Merek berpengaruh signifikan terhadap keputusan pembelian.

\section{Pembahasan atau Hasil Analisis Secara Simultan}

Berdasarkan hasil pengujian serta analisis yang telah dilakukan pada penelitian ini membuktikan bahwa Iklan Televisi dan Citra Merek secara simultan berpengaruh signifikan terhadap keputusan pembelian produk merek Wardah di Kota Palu. Berdasarkan tabel rekapitulasi regresi linear berganda dapat dilihat pengaruh hasil uji determinasi Adjusted $R$ Square sebesar 0.614. Nilai tersebut dapat diartikan bahwa seluruh dimensi bebas yakni iklan televisi dan citra merek mempunyai konstribusi secara bersama-sama sebesar $61,4 \%$ terhadap variabel terikat yaitu terhadap keputusan pembelian produk merek Wardah di Kota Palu. Sedangkan sisanya $(100 \%-61,4 \%=38,6 \%)$, dipengaruhi oleh variabel lain yang tidak diteliti misalnya variabel harga, kualitas produk, dan lain-lain yang secara teori dan hasil-hasil penelitian sebelumnya berpengaruh terhadap keputusan pembelian.

Hasil penelitian ini sejalan dengan penelitian yang dilakukan oleh Nela, Handoyo dan Sari (2012) yang menyatakan bahwa citra merek, kualitas produk, harga, dan promosi secara simultan berpengaruh signifikan terhadap keputusan pembelian kartu perdana TelkomFlexi, selain itu juga ada Jacky dan Willem (2014) yang menyatakan hasil penelitiannya yaitu citra merek, kualitas produk, dan promosi berpengaruh signifikan terhadap keputusan pembelian Parfum Excite Oriflame, penelitian sebelumnya juga dilakukan oleh Wibowo dan Karimah (2012), mereka menyatakan bahwa iklan televisi dan harga berpengaruh signifikan terhadap keputusan pembelian sabun lux pada pengunjung Mega Bekasi Hypermall.

\section{Pembahasan atau Hasil Analisis Secara Parsial Iklan Televisi $\left(\mathbf{X}_{1}\right)$}

Iklan televisi merupakan kegiatan periklanan yang dilakukan dengan menggunakan media televisi dengan tujuan agar lebih efektif untuk memasarkan produk secara luas. Adapun dimensi-dimensi yang 
digunakan untuk mengukur elemen iklan televisi adalah nilai informasi, keyakinan membeli, dan citra sosial.

Hasil penelitian yang didapatkan pada variabel iklan televise, nilai mean tertinggi ada pada indikator memberitahu mengenai produk baru, dengan mean atau rata-ratanya yang paling dominan sebesar 4.16. Hal ini menunjukkan responden setuju bahwa iklan Wardah di televisi telah memberitahu produk-produk apa saja yang baru dikeluarkan oleh Wardah dan responden mengetahui produk baru Wardah dari iklan Wardah di televisi. Kemudian nilai mean tertinggi kedua ada pada indikator memberitahu tentang merek yang sedang dibutuhkan dengan nilai mean atau rata-rata sebesar 4.00. Pada indikator tersebut, kebanyakan responden menanggapi setuju bahwa iklan Wardah di televisi memberitahu kepada pemirsa bahwa Wardah merupakan merek yang sedang dibutuhkan oleh pemirsa. Lalu nilai mean tertinggi ketiga dari sembilan indikator yaitu ada pada indikator memberitahu produk yang sedang tersedia di pasar dengan nilai mean atau rata-rata sebesar 3.89. Sebagian besar responden menanggapi pernyataan pada indikator tersebut dengan pernyataan setuju yaitu sebanyak 45 orang dari jumlah total responden yaitu 75 responden. Hal ini menunjukkan responden setuju bahwa mereka mengetahui produk-produk Wardah yang sedang tersedia atau yang sedang dijual di pasaran melalui iklan Wardah di televisi.

Berdasarkan hasil penelitian ini, indikator-indikator yang digunakan untuk mengukur iklan televisi berpengaruh signifikan terhadap keputusan pembelian. Hal ini menunjukan bahwa seseorang dalam melakukan keputusan pembelian didasari oleh informasi yang diterima konsumen yaitu melalui media informasi seperti televisi. Adanya iklan Wardah di televisi, konsumen dapat memahami produk yang diiklankan dan konsumen memutuskan untuk membeli dan menggunakan produk merek Wardah di Kota Palu biasanya tertarik atau menjadi yakin saat melihat iklan Wardah di televisi yang memberitahu informasi mengenai produk baru atau produk yang sedang dicari oleh konsumen. Hasil penelitian ini mendukung penelitian sebelumnya yang dilakukan oleh Wibowo dan Karimah (2012) yang menyatakan bahwa iklan televisi secara parsial berpengaruh signifikan terhadap keputusan pembelian sabun lux pada pengunjung Mega Bekasi Hypermall.

\section{Citra Merek $\left(\mathbf{X}_{2}\right)$}

Citra terhadap merek berhubungan dengan perilaku atau sikap konsumen yang berupa keyakinan terhadap suatu merek. Konsumen yang memiliki citra positif terhadap suatu merek, akan lebih memungkinkan untuk melakukan pembelian terhadap merek tersebut. Adapun indikator-indikator yang digunakan untuk mengukur elemen citra merek adalah pengenalan, reputasi, daya tarik, dan kesetiaan merek.

Penelitian yang dilakukan pada variabel citra merek dimana merek memiliki ciri khas merupakan indikator yang memiliki nilai mean atau rata-rata tertinggi yaitu sebesar 4.55. Hal ini menunjukkan responden setuju bahwa Wardah memiliki ciri khas yaitu berlabel "halal" dan responden setuju bahwa ciri khas tersebut dapat memengaruhi konsumen untuk membeli dan menggunakan produk Wardah. Kemudian nilai mean tertinggi kedua ada pada indikator merek mudah diingat yaitu dengan nilai mean atau rata-rata sebesar 4.31. Hal ini dikarenakan hampir sebagian responden memberi tanggapan setuju pada pernyataan tersebut, yang berarti responden setuju bahwa merek Wardah mudah untuk diingat dibenak mereka dan hal tersebut memudahkan mereka untuk mengenal merek Wardah dan produknya. Lalu pada urutan ketiga nilai mean tertinggi ada pada indikator merek mudah diucapkan dengan nilai mean atau rata-rata sebesar 4.27. Hal tersebut menunjukkan responden setuju bahwa merek "Wardah" mudah untuk diucapkan, dengan begitu merek Wardah akan mudah tertanam di dalam benak konsumen.

Berdasarkan hasil penelitian ini, indikator-indikator yang digunakan untuk mengukur citra merek berpengaruh signifikan terhadap keputusan pembelian produk merek Wardah. Hal ini membuktikan bahwa konsumen dalam melakukan suatu pembelian selalu memperhatikan citra dari merek suatu produk. Citra merek memengaruhi keputusan pembelian dengan daya tarik atau kelebihan yang dimiliki oleh produk, keunikan produk seperti tampilan produk, seperti merek yang mudah diingat, dll. Berdasarkan hal tersebut dapat dikatakan bahwa citra merek dapat memengaruhi keputusan pembelian produk merek Wardah di Kota Palu.

Hasil penelitian ini sejalan dengan penelitian sebelumnya yang dilakukan oleh Nela, Handoyo dan Sari, mereka menyatakan bahwa citra merek secara parsial berpengaruh signifikan terhadap keputusan pembelian kartu perdana TelkomFlexi di Kecamatan Kota Kudus Kabupaten Kudus. Penelitian juga 
dilakukan oleh Indah Siti Mahmudah dan Monika dimana hasil penelitiannya menyatakan bahwa citra merek secara parsial berpengaruh signifikan terhadap keputusan pembelian Pond's Flawless White.

\section{PENUTUP \\ Kesimpulan}

Berdasarkan hasil penelitian yang telah dijabarkan, maka diperoleh kesimpulan mengenai pengaruh iklan televisi dan citra merek terhadap keputusan pembelian produk merek Wardah di Kota Palu, sebagai berikut:

1. Iklan Televisi dan Citra Merek secara simultan berpengaruh signifikan terhadap keputusan pembelian produk merek Wardah di Kota Palu.

2. Iklan Televisi secara parsial berpengaruh signifikan terhadap keputusan pembelian produk merek Wardah di Kota Palu.

3. Citra Merek secara parsial berpengaruh signifikan terhadap keputusan pembelian produk merek Wardah di Kota Palu.

\section{Saran}

Berdasarkan kesimpulan yang telah diuraikan sebelumnya, maka saran-saran yang tepat menyangkut kegunaan penelitian ini dapat diuraikan sebagai berikut:

1. Kepada PT Paragon Technology and Innovation (PTI) perlu untuk melakukan inovasi terhadap promosi yang dilakukan khususnya pada iklan yang menggunakan media televisi, karena hal itu dapat memengaruhi konsumen dalam melakukan keputusan pembelian. Dari penelitian yang dilakukan pada variabel iklan televisi didapatkan nilai mean tertinggi ada pada indikator memberitahu mengenai produk baru. Untuk itu, pihak PTI perlu untuk terus mempertahankan dan mengembangkan iklan melalui media televisi dalam hal ini yaitu mengembangkan informasi pada iklan Wardah di televisi yang memberitahukan konsumen mengenai produk baru apa saja yang dikeluarkan oleh Wardah.

2. Pihak PTI perlu untuk mengembangkan iklan Wardah di televisi dengan memperhatikan informasi yang diberikan apakah dapat membuat konsumen terbantu dalam mengambil keputusan. Misalnya dengan menambahkan kalimat-kalimat yang menyatakan bahwa produk Wardah merupakan produk yang tidak perlu diragukan lagi untuk digunakan.

3. Kepada PT Paragon Technology and Innovation (PTI) perlu untuk mempertahankan ataupun meningkatkan citra dari merek Wardah khususnya pada ciri khas dari merek Wardah yaitu berlabel halal. Misalnya dengan membuat inovasi pada produknya, membuat iklan yang menarik baik di media televisi, radio, ataupun media cetak tentang ciri khas dari Wardah yaitu berlabel "halal" yang dapat membuat persepsi konsumen terhadap Wardah menjadi baik sehingga dapat meningkatkan keputusan pembelian secara maksimal.

4. Pihak PTI perlu meningkatkan citra dari merek Wardah agar terkesan modern. Misalnya dengan mengangkat brand ambassador yang terkenal memiliki citra yang baik dan tampilan yang modern di mata konsumen dengan harapan hal tersebut akan tertanam di dalam benak konsumen.

5. Kepada peneliti selanjutnya disarankan untuk memasukkan variabel lain seperti variabel harga, kualitas produk dan lain-lain, selain yang digunakan dalam penelitian ini sehingga lebih dapat mengukur sebab-sebab yang mempengaruhi keputusan pembelian produk merek Wardah di Kota Palu, selain itu juga diharapkan untuk menggunakan ukuran sampel yang lebih besar dari jumlah sampel yang digunakan pada penelitian ini sehingga keakuratan hasil penelitian akan lebih terjamin. Penulis juga menyarankan untuk tidak mengambil objek penelitian di sebuah Mall atau toko kosmetik lainnya yang merupakan tempat umum. Hal ini menyebabkan kurangnya konsentrasi responden dalam mengisi kuesioner karena suasana yang kurang kondusif dan agak ramai, sehingga penilaian yang diberikan kurang objektif.

\section{REFERENSI}

Evelina, N., Handoyo, D., \& Listyorini, S. (2012). Pengaruh Citra Merek, Kualitas Produk, Harga, dan Promosi Terhadap Keputusan Pembelian Kartu Perdana TelkomFlexi, 1-11.

Ghozali, I. (2013). Aplikasi Analisis Multivariat Dengan Program IBM SPSS 21 (7 ed.). Semarang: Universitas Diponegoro. 
Riskiana, S.

Istijanto. (2005). Aplikasi Praktis Riset Pemasaran. Jakarta: PT Gramedia Pustaka Utama.

Kotler, P., \& Armstrong, G. (2008). Prinsip-prinsip Pemasaran (12 ed.). Jakarta: Erlangga.

Kotler, P., \& Keller, K. L. (2009). Manajemen Pemasaran (13 ed.). Jakarta: Erlangga.

Kotler, P., \& Keller, K. L. (2012). Marketing Management (14 ed.). New Jersey: Prentice-Hall.

Rangkuti, F. (2009). Strategi Promosi yang Kreatif dan Analisis Kasus Integrated Marketing Communication. Jakarta: PT Gramedia Pustaka Utama.

Sugiyono. (2012). Metode Penelitian Kuantitatif, Kualitatit Dan R\&D. Bandung: Alfabeta.

Sugiyono. (2014). Metode Penelitian Bisnis (Pendekatan Kuantitatif, Kualitatif dan R\&D (18 ed.). Bandung: Alfabeta.

Sugiyono. (2015). Metode Penelitian Kombinasi (Mixed Methods). Bandung: Alfabeta.

Sugiyono. (2016). Metode Penelitian Administrasi dilengkapi Metode R\&G. Bandung. Alfabeta.

Tjiptono, F. (2011). Pemasaran Jasa. Malang: Bayumedia.

Wardah. (t.t.). Diambil 25 Februari 2018, dari http://www.wardahbeauty.com/

Wibowo, S. F., \& Karimah, M. P. (2012). Pengaruh Iklan Televisi dan Harga Terhadap Keputusan Pembelian Sabun Lux, 3. 